\title{
Special Collections: What Are They and How Do We Build Them? ${ }^{1}$
}

\author{
VANESSA KING ${ }^{2}$
}

This article provides a very brief introduction to practical information useful for building special collections at an academic law library rather than addressing theory or the history of special collections. ${ }^{3}$

\section{What are Special Collections and Why Should We Build Them?}

Special collections can be quite broad in terms of materials and format. One authoritative definition is "library and archival materials in any format (e.g., rare books, manuscripts, photographs, institutional archives) that are generally characterized by their artifactual or monetary value, physical format, uniqueness or rarity, and/ or an institutional commitment to long-term preservation and access. They generally are housed in a separate unit with specialized security and user services. Circulation of materials usually is restricted."4

We should build special collections for purposes of preservation, research, and teaching. It is important to preserve rare and valuable materials in formats that will remain accessible to scholars and other researchers. Teaching with primary sources is increasingly valued in the humanities and, in law school, courses such as legal history and selected seminars. Finally, as the perceived value of law libraries continues to shift away from general collections and toward services, building focused and strong special collections can allow a library to once again distinguish itself in terms of its collection.

\section{What Should We Collect?}

Options include rare books, manuscripts, ephemera, photographs, institutional and organizational archives, and oral histories. Within rare books one may wish to focus collecting in any of the following areas:

- English law, pre and post-17005

- American law, pre and post-independence 6

${ }^{1}$ C Vanessa King 2018. This is a companion to a piece published by my colleague, Jason LeMay, in issue 46.1 of the INTERNATIONAL JOURNAL OF LEGAL INFORMATION. It is a summary of the text of an oral presentation, the first session in a pre-conference workshop titled, Well, Isn't that Special? A How-To Workshop on Creating and Using Archives and Special Collections in a Legal Research Context. It was delivered at the International Association of Law Libraries, 36th Annual Course on International Law and Legal Information, Civil Rights, Human Rights, and Other Critical Issues in U.S. Law, Emory University, Atlanta, Georgia, October 22-26, 2017. The presentation was 25 minutes long and included PowerPoint slides, a handout, and physical examples of selected rare materials from Special Collections at the Hugh F. MacMillan Law Library, Emory University School of Law.

2 The author is the Assistant Law Librarian for Special Collections, Emory University School of Law, Atlanta, Georgia, USA.

${ }^{3}$ This article does not specifically discuss born-digital materials or digitization.

${ }^{4}$ Jackie M. Dooley and Katherine Luce (2010), Taking Our Pulse: The OCLC Research Survey of Special Collections and Archives, OCLC RESEARCH, https://www.oclc.org/content/dam/research/publications/library/2010/2010-11.pdf.

${ }^{5}$ Pre-1700 there was a general focus on legal practice versus post-1700 when the focus shifted more toward legal theory. This time period also represents the transition from manuscript to print. Law Books: History and Connoisseurship, Rare Book School course taught by Mike Widener, June 2016. See reference works by John H. Baker, Theodore F.T. Plucknett, and William S. Holdsworth.

${ }^{6}$ See reference works by Morris L. Cohen, Lawrence M. Friedman, Grace E. Macdonald, and the Women's Legal History Biography Project, http://www.law.stanford.edu/library/womenslegalhistory/. 
- Roman and Canon law (an enormous body of literature) ${ }^{7}$

- European, Latin American, and International law (including human rights and the law of war). ${ }^{8}$

Reference sources are very useful when building a rare book collection, as well as when conducting research within the collection.

When building a rare book collection it is also helpful to take into account the format and binding of the books you're considering acquiring. Format refers to the number of times the printed sheets of paper were folded before gathering and also relates to the size of the book. Examples of format include folio, quarto, octavo, and duodecimo. It can be important to remember that folios require over-sized shelving, which is scarce in many law libraries. Calfskin and vellum (untanned calfskin) are common bindings, each of which present different preservation concerns. Information about format and binding is routinely included in dealer descriptions of rare books. However, to understand the book descriptions in dealer catalogs it is necessary to be familiar with the specialized terminology used (such as hinges, joints, edges, margins, uncut, unopened, endpapers, pastedown, frontispiece, incunable, boards, contemporary, re-backed, foxing, and sophisticated). ${ }^{9}$

Manuscript collections often include the professional, and sometimes the personal, papers of jurists (both judges and lawyers), law professors, other legal scholars, and activists. These collections can be invaluable to historians, students of history, and many other types of researchers. Ephemera are collectible memorabilia (such as programs, pamphlets, political leaflets, and flyers) that were often printed for a specific occasion and expected to have only short-term usefulness. Ephemera are often found within organizational records, as well as personal and professional papers (especially papers of activists for social and legal change) and are usually an eye-catching addition to any exhibition.

Collections of historical photographs are greatly appreciated by law school alumni, as well as by members of the law school development and alumni relations and marketing and communications departments. It is likely that your institution already holds a wealth of old photographs, which are perhaps partly unorganized and unlabeled. It is probably worthwhile having these materials processed by an archivist and finding aids for them created. Finally, institutional and organizational archives include organization records, special project and program records, as well as law school and law library records.

\section{Building Focused and Well-Defined Collections}

The most important tool for building the most useful collections will be a collection development policy or plan specifically for special collections at your law library. Although this policy should be as well thought out as possible, keep in mind that it's also a guide that will periodically need to be updated and revised. As you draft and revise your collection development policy for special collections, it will be particularly important to understand the needs of your researchers and other users, including what those needs are likely to be if you further develop and promote your law library's special collections. Finally, you will also want to consider what is important to your supporters including resource allocators, donors, and potential donors. Consider including the following information in your collection development plan for special collections:

- Subject areas in which to collect

- Region and time period

- Is your library interested in collecting works by a particular legal scholar?

- Types of materials and records to collect

- Collecting priorities and resources available

- Programs supported by each collection (research, publications, courses, etc.)

- Guidelines for deaccessioning.

Ultimately, what to collect will most likely depend primarily on the existing strengths of your law library and institution. In fact, your library may already hold at least a few special collections that you could consider developing

\footnotetext{
${ }^{7}$ See reference works by Michael H. Hoeflich, Kenneth Pennington, and Roman Law Resources, http://www.iuscivile.com/.

${ }^{8}$ See reference works by Theodore Besterman, the Grotius Society, and edited by Alexander Orakhelashvili.

${ }^{9}$ See John Carter, ABC for Book Collectors (8th ed. 2004), https://www.ilab.org/articles/john-carter-abc-book-collectors, and alibris, Glossary of Book Terms, https:/www.alibris.com/glossary/glossary-books\#a.
} 
further. ${ }^{10}$ Building on the existing strengths of your collection and institution will lead to more use of your collections. Moreover, as much as possible it is helpful to create synergy among archives, manuscripts, and rare book collections, so they will build on each others' strengths and perhaps be even more useful to researchers.

Even though the goal is to build focused and well-defined collections, try to also be flexible and ready to take advantage of any great opportunity, such as the chance to begin building a new and unique collection after a substantial donation of materials. Finally, consider collecting at least a small amount of more non-traditional items such as broadsides, wax seals, activist t-shirts, and awards. These types of items can be less convenient to house, but will be particularly visually appealing as eye-catching additions to future exhibitions.

\section{Working with Members of the Antiquarian Book Trade}

In my experience, rare book dealers have been wonderful to work with and their expertise is invaluable - so let them help you and make your life a little bit easier. You can begin by going to recommended dealer websites and requesting electronic and/or print catalogs of their recent acquisitions. ${ }^{11}$ It is also usually possible to create a "want list" from the dealer's website, which can be helpful.

Furthermore, if you share a summary of your collection development policy or plan for special collections with selected rare book dealers, some dealers will periodically send relevant quotes to you, often after searching your catalog. It is polite to always reply to them as promptly as you can even if you aren't interested in the item they've quoted. Additionally, you may want to let them know whether you'll be interested in a book if another campus library holds a different edition, or if your library already has access to a digitized version through a subscription database. And whenever you have the opportunity, it is very enjoyable and educational to get to know antiquarian book dealers in person. You can often meet with them at conferences and book fairs and, even better, visit their physical shop if you happen to work or be conferencing anywhere nearby.

Finally, know that you can return a rare book to the dealer, in a timely manner, if you aren't satisfied with it (for example, if you find mold inside the book that the dealer missed). Finally, don't hesitate to ask a rare book dealer for a few (additional) photos of a book you're considering purchasing, especially if you're unsure about the condition of the item based on the dealer's description - they will be happy to provide photos, as well as additional information about the book if more is available.

Additional sources for acquiring rare materials include auctions, book fairs, and eBay (although be very careful if attempting to purchase rare materials through eBay). The Antiquarian Booksellers' Association of America (ABAA) and the International League of Antiquarian Booksellers (ILAB) both offer many helpful resources. ${ }^{12}$

\section{Assistance from Faculty Members and Members of the Law School Administration}

If there are faculty members at your law school with subject matter expertise in any of your collecting areas for special collections, request their input concerning building the library's special collections. You may want to begin by letting specific faculty members know you're developing special collections in areas of law related to their scholarship. Then you can share relevant new acquisitions with those law professors, as well as let them know you'll always appreciate suggestions for future acquisitions. You can also ask for the opinion of one of these faculty members if you're unsure whether a book or manuscript collection is worth acquiring for your institution's special collections. In addition, let faculty members who work in areas of focus for special collections

\footnotetext{
${ }^{10}$ Once you've evaluated any existing special collections your library may hold, you may want to weed out or deaccession any unwanted items. Also, after an evaluation of your library's general collection you may be able to identify rare and valuable materials that should be transferred to special collections. See Association of College and Research Libraries (ACRL), Guidelines on the Selection and Transfer of Materials from General Collections to Special Collections (4th ed. 2016), http://www.ala.org/acrl/standards/selctransfer.

${ }^{11}$ Lawbook Exchange, https://www.lawbookexchange.com/ and Meyer Boswell Books, http://www.meyerbos.com are two of the rare law book dealers with whom we work most often. For a list of recommended dealers see Lyonette Louis-Jacques, Antiquarian/Rare Books Vendors and Dealers: Foreign and International Law, DipLawMatic Dialogues (October 24, 2016), https://fcilsis.wordpress.com/2016/10/24/antiquarianrare-books-vendors-and-dealers-foreign-and-international-law/.

12 See ABAA, https://www.abaa.org/about-antiquarian-books, and ILAB, https://www.ilab.org/.
} 
development know that the law library would welcome the opportunity to accept related materials from donors. ${ }^{13}$ And also, remember that faculty can be donors as well, both before and after they've retired. ${ }^{14}$ Finally, if approached, faculty will often donate or transfer records of clinics, centers, projects, or programs they direct to the law library archives.

Members of the law school administration, particularly those who work in the Dean's Office, development and alumni relations, and marketing and communications departments, can often assist with the transfer of historically important records from law school departments to the law library archives. Considerations involving the temporary restriction of certain types of records and issues of privacy and confidentiality, including the disposition of surplus materials, are often much more important to administrators transferring records than to other types of donors. Therefore, it is helpful to address such concerns early in the discussion about the transfer of a group of institutional records.

\section{Appraisal of Materials and Donor Relations}

Appraisal, in an archival context, is often largely based on whether an offered selection of materials would add value to your library's existing special collections. ${ }^{15}$ In addition to looking to your collection development policy for special collections for guidance, you may also want to ask the following questions:

- Does this work fit well within my library's larger collection?

- What is the value of this information?

- What will be the cost of processing, maintaining, and making this material accessible and will it be worthwhile for our library?

Developing skills for accepting, and especially for declining, donations of materials is important and these matters are often delicate, therefore, excellent communication and interpersonal skills are essential. Soon after accepting a donation you may want to announce the gift on your law library's website, and the law school may want to do the same in addition to including a piece about the gift in various alumni publications. However, before you agree to curate an exhibit featuring the gift make sure you have the appropriate resources to do so and that the donor's expectations align with what you'll be able to produce.

It is sometimes necessary to decline the donation of offered materials. In this event, great care should be taken not to offend the potential donor. Reasons for declining a donation can include: the materials do not fit within our collection development policy; cataloging or processing the materials and continuing to make them accessible would stretch library resources too thin; the collection is too large for our available physical space. Finally, keep in mind that you'll probably occasionally be working with bereaved donors, meeting them at various stages in their grieving process, so of course you'll want to be extra gentle, respectful, understanding, and patient with these individuals.

\section{Sources for Continued Professional Education}

\section{Archives}

- Society of American Archivists (SAA): https://www2.archivists.org/prof-education/continuing-education

- Society of Georgia Archivists (SGA): https://soga.wildapricot.org/education

- Georgia Archives Institute: http://www.georgiaarchivesinstitute.org/

\section{Rare Books}

- Rare Book School course taught by Mike Widener - Law Books: History \& Connoisseurship: http://rarebookschool.org/courses/collections/c85/

- RBMS (ACRL's Rare Books and Manuscripts Section): http://rbms.info/committees/membership_and_professional/educational_opportunities/

${ }^{13}$ For example, a faculty member may know that the family of a colleague (law professor, judge, or attorney) who has died is looking for a research library to archive their relative's papers.

${ }^{14}$ In addition, an attorney or legal scholar may leave their papers to a trusted faculty colleague in their will.

${ }^{15}$ In an archival context, appraisal is the process of determining whether records and other materials have permanent value. Society of American Archivists, Appraisal, A Glossary of Archival and Records Terminology, https://www2.archivists.org/ glossary/terms/a/appraisal. 